\title{
Ambtenaren in stad en land in de Nederlanden. Socio-professionele evoluties (veertiende tot zestiende eeuw)*
}

\author{
W. PREVENIER
}

Het rapport dat ik dit Congres van het NHG voorleg heeft veeleer het karakter van een aantal probleemstellingen dan van pasklare oplossingen. Het is, dunkt me, duidelijk dat de fundamentele verschuivingen in de ambtenarenwereld niet alle synchronisch zijn, en ook bepaald niet samenvallen met de overgang van Middeleeuwen naar Nieuwe Tijd. Een aantal structurele veranderingen van technische of van sociologische aard vallen veeleer circa 1300 of 1400, en 1500 geeft in een aantal opzichten de doortrekking te zien van begonnen evoluties, eventueel met de nodige schaalvergroting.

Dat is alvast het geval met het eerste facet dat ik wil aanstippen, het doorbreken van de standenmuur. Oorspronkelijk, tot in de twaalfde eeuw, bestond er nagenoeg een identiteit van 'sociale stand' en 'sociale functie', in die zin dat de derde stand zich met handel en industrie inliet, de adel met militaire en raadgevende functies, de clerus met kerkelijke functies maar tegelijk de hele ambtenarij monopoliseerde. In geheel West-Europa komt tot de twaalfde eeuw een nagenoeg vaste identiteit voor tussen de vorstelijke kanselarijen en de vorstelijke kapellen. Tot 1291 zijn ook de kanselarij en administratie der graven van Holland exclusief in handen van geestelijken geweest ${ }^{1}$. Maar in bepaalde sectoren, bijvoorbeeld de administratie van het grafelijk domein in Vlaanderen is de laïcisering vroeger ingezet: in 1187 komen reeds acht leken voor tegen vijftien geestelijken, en in het begin der dertiende eeuw nemen ze zelfs de overhand ${ }^{2}$. Uiteraard verdwijnen de geestelijken niet als ambtenaren ; de kanselier Willem van Auxonne in Vlaanderen onder Lodewijk van Nevers (eerste helft veertiende eeuw) en kanselier Jean Canard onder Filips de Stoute zijn nog steeds clerici; in de hele vijftiende eeuw waren nog steeds geestelijken aanwezig in het bestuursapparaat van de stad Brussel ${ }^{3}$. Alleen zijn alle genoemde

* Als voordracht gehouden op het congres van het NHG te Driebergen, 23 oktober 1971.

1. J. Fleckenstein, Die Hofkapelle der deutschen Könige. Schriften der MGH, I (Stuttgart, 1959);

H. W. Klewitz, 'Kanzleischule und Hofkapelle', Deutsches Archiv, IV (1940) 224-228; J. G. Kruisheer, De oorkonden en de kanselarij van de graven van Holland tot 1299 ('s-GravenhageHaarlem, 1971) 195-196, 213.

2. A. Verhulst-M. Gysseling, Le compte général de 1187, connu sous Ie nom de 'Gros Brief' et les institutions financières du comté de Flandre au XII siècle (Brussel, 1962) 106-119.

3. J. Pacquet, 'La collaboration du clergé a 1'administration des villes de Bruxelles et d'Anvers au 14e et 15e siècles', Le Moyen-âge, LVI (1950) 357-372. Over Willem van Auxonne: R. Monier, 
geestelijken nu ook tevens legisten, en is bovendien hun monopoliepositie weggevallen. In de vorstelijke omgeving is er vanaf de eerste helft der veertiende eeuw een echte invasie van handige Italiaanse financiële specialisten, allen leken: Nicolas Guidouche, Simon de Mirabello, Vanne Guy, Thomas Fini en Oddine Naerbone waren ontvangers en financiers der Vlaamse graven, conté Gualterotti werd kanselier, Ottelin Machet watergraaf, en hetzelfde deed zich voor bij de hertog van Brabant, de Vlaamse steden en de Franse koning ${ }^{4}$.

Het blijft een intrigerende en open vraag of de omschakeling naar de volkstalen in de stedelijke rekeningen rond 1300 een gevolg is van de aflossing van latijns-georiënteerde clerici door leken, of van de algemene democratiseringsgolf die de administratie van de steden toegankelijker wilde maken voor de massa, en dan meteen de weg naar het ambtenarenapparaat vrijmaakte voor minder latijns georiënteerde leken en burgers ${ }^{5}$.

Het is evident dat elke sociale groep zich in de maatschappij op een of andere wijze tracht te valoriseren: de Vlaamse stedelingen realiseerden dit door hun economische activiteit en door hun dominante rol in de standenvertegenwoordiging; de adel kwam onder de Vlaamse graven der veertiende eeuw en de hertogen der vijftiende eeuw aan bod in representatieve functies der hofhouding of in society-organen zoals de Orde van het Gulden Vlies; de clerus vroeger veilig opgesloten in de ambtenarenwereld, werd daar ten dele uit verdreven, doch niet zonder compensaties. Vooral de Bourgondische vorsten wisten als het ware een groot deel van de institutionele Kerk te accapareren, te herleiden tot een stuk van het Bourgondisch staatsapparaat, $\mathrm{nl}$. door een mooi gedoseerde benoemingspolitiek bij de vacatures in bisdommen en abdijen, die men zodanig met vertrouwelingen opvulde dat de kerkelijke hiërarchie in de Nederlanden een dociel instrument werd van de overheidspolitiek ${ }^{6}$.

'Une source nouvelle pour 1'histoire administrative de la Flandre. Le registre de Guillaume d'Auxonne', Revue du Nord, X (1924) 17-20. Over Jean Canard, bisschop van Atrecht, proost van St. Donatiaan Brugge: E. Giard, Jean Canard, avocat du roi au Parlement, chancelier de Bourgogne, Positions Thèses Ecole des Chartes (Parijs, 1902) 23-29.

4. P. Rogghé, 'Italianen te Gent in de XIVe eeuw', Bijdragen voor de Geschiedenis der Nederlanden, I (1946) 197-226; P. Rogghé, 'Simon de Mirabello in Vlaanderen', Appeltjes van het Meetjesland, IX (1958) 5-56; P. Rogghé, 'Het Florentijns geslacht Machet in Vlaanderen', in: Ibidem, XVI (1965) 188-196; H. van Werveke, De Gentsche stadsfinanciën in de middeleeuwen (Brussel, 1934)274-281.

5. J. Dhondt, 'Conclusions générales', in: Financiën en boekhouding der steden van de lie tot de 16e eeuw, Intern. Colloq., Blankenberge 1962, Pro Civitate, VII (Brussel, 1964) 367, neemt aan dat de ommezwaai naar de volkstaal in de boekhouding gevolg is van de vorming van een nieuw type ambtenaar in de stedelijke lekenscholen (zonder latijn).

6. Over de orde van het Gulden Vlies zie: Th. de Limburg Stirum, in: Het Gulden Vlies. Vijf eeuwen kunst en geschiedenis. Catalogus (Brugge, 1962) 35-81; over de kerk in dienst van het Bourgondisch staatsapparaat: E. de Moreau, Histoire de l'Eglise en Belgique, IV (Brussel, 1949) 41-123; A. G. Jongkees, Kerk en Staat in Holland en Zeeland onder de Bourgondische hertogen (Groningen, 1942) passim; W. Prevenier, 'De verhouding van de clerus tot de locale en regionale overheid in het graafschap Vlaanderen in de late Middeleeuwen', in: Bronnen voor de religieuze geschiedenis 


\section{W. PREVENIER}

De ambtelijke wereld is een wereld waarin, reeds in de twaalfde eeuw, vrij carière kan gemaakt worden door homines novi. Ook dat is een doorbreking van de standsmuren. Mensen als Thomas Becket in Engeland, als Robrecht van Aire in Vlaanderen, waren van heel bescheiden komaf, en klommen niettemin in de twaalfde eeuw op tot de topfunctie van kanselier, respectievelijk van de Engelse koning en de graaf van Vlaanderen. Maar het is evenzeer duidelijk dat dergelijke bliksemcarrières in de twaalfde eeuw nog sterke weerstanden en naijver opriepen. Beide genoemde personages werden vermoord door hun vijandig gezinde clans, door een bepaald establishment dat kennelijk het snel doorlopen van eenjcurriculum niet kon verkroppen ${ }^{7}$. Natuurlijk hebben hier nog andere factoren gespeeld, zoals het optreden van deze ambtenaren tegen concrete misbruiken. De reactie was dus tevens een reactie tegen een bepaalde staatspolitiek. Is het misschien zo dat het publiek zijn theoretische en ideologische bezwaren tegen een zekere staatspolitiek projecteert op de concrete mensen die deze politiek uitvoeren, en dan nog eerder op de topambtenaar dan op de vorst? Wanneer op het einde der vijftiende eeuw het verzet tegen de Bourgondische politiek in de Nederlanden zijn hoogtepunt bereikt, wordt de hertogin Maria nog met enig ontzag en sympathie bejegend, doch twee van haar hoofdambtenaren, Hugonet en Humbercourt, worden te Gent in 1477, ondanks haar aandringen tot amnestie, ter dood gebracht, na een schijnproces en zonder werkelijke juridische argumenten, 'om het volk tevreden te stellen'.

Een tweede beweging, die logisch met de vorige samenhangt, is de ontwikkeling van de ambtenarengroep tot een sociale stand met een eigen gelaat. Een notaris van de Vlaamse graaf uit de twaalfde eeuw, zoals Galbert van Brugge, een kanselier van de Henegouwse graaf, zoals Giselbert van Bergen, spreekt nog duidelijk van 'wij-geestelijken' en niet van 'wij-ambtenaren'. De ambtenaar uit de twaalfde eeuw identificeert zich nog met zijn traditionele sociale stand, bv. Galbert met de geestelijken der Brugse St. Donatiaanskerk ${ }^{9}$.

van België, middel, en moderne tijden, Bibliothèque de la Revue d'Histoire Ecclésiastique, XLVII (Leuven, 1968) 30-34.

7. H. van Werveke, Thomas Becket, Filips van de Elzas en Robrecht van Aire, Meded. Kon. VI. Ak. v. Wet. v. België, Kl. Lett. (Brussel, 1970). Ook in de dertiende-veertiende eeuw zijn dergelijke carrières bij mensen van lage afkomst mogelijk: J. Buntinx, De audiëntie van de graven van Vlaanderen (Brussel, 1949) 96.

8. F. W. N. Hugenholtz, 'Crisis en herstel van het Bourgondisch gezag, 1477-1493', in: Algemene Geschiedenis der Nederlanden,IV (Utrecht, 1952) 5; G. H. Dumont, Marie de Bourgogne (Brussel, 1943) 132. Dergelijke projectie doet zich al vroeger voor in het begin der vijftiende eeuw, wanneer de Gentenaars de voorzitter van de Raadkamer Simon van Formelis verjagen uit zijn functie, precies de man, die in 1400 nog stadspensionaris was geweest van Gent, zie: P. Rogghé, 'De Gentse klerken in de 14e en 15e eeuw', Appeltjes van het Meetjesland, XI (1960) 120, noot 142.

9. H. Pirenne, Histoire du meurtre de Charles le Bon, comte de Flandre par Galbert de Bruges (Parijs, 1891) ii en 165 (hfdst. cxiv); J. B. Ross, Galbert of Bruges. The Murder of Charles the Good 
Het is me niet geheel duidelijk wanneer precies de ommezwaai naar een nieuwe situatie zich voordeed, doch het staat vast dat in de vijftiende eeuw de ambtenarenstand als sociale groep een sociologische realiteit is. Doch reeds in de veertiende eeuw tekent zich de vorming af van ambtenarenfamilies, met veel onderlinge familierelaties ${ }^{10}$. Om alle misverstand te voorkomen wil ik er op wijzen dat men bij de term 'ambtenarenstand' essentieel denkt aan officiumdragers, van welke traditionele sociale stand ook. Sociologisch indentificeert deze groep zich echter grotendeels met bv. de raadsheren van de vorsten die niet noodzakelijk een officium in de strikte zin bekleden en met het hofmilieu. Het was - in tegenstelling met de vroegere Middeleeuwen - in de veertiende eeuw al belangrijker tot een duidelijke sociale groep dan tot een juridische groep te behoren. Wat zijn de kenmerken van de sociologische stand der laat-middeleeuwse ambtenaren, in de ruimere zin? De essentiële trekken liggen op het vlak van het materiële voordeel en het sociaal prestige. Nastreven van materieel voordeel door omkoperij is natuurlijk niet het monopolie der ambtenaren, maar de verleiding en de kansen zijn hier wellicht groter geweest. Het is toch wel typisch dat in de vijftiende eeuw zoveel hertogelijke ordonnanties $\left(1414,1431\right.$ en 1446) zich richten tegen misbruiken op financieel vlak ${ }^{11}$; in 1446 trof Filips de Goede maatregelen om te verhinderen dat zijn commissarissen nog verder zouden omgekocht worden met goud en edelstenen bij het aanstellen der schepenen en het kontroleren der rekeningen ('et maintesfois ont mis en lois ceulx qui plus en donnoient, sanz avoir regard a leur preudommie et souffisance' ${ }^{\prime 2}$ ).

In het grote conflict tussen de vijandige clans der Rolins en Croys na 1450 speelde de financiële fraude een hoofdrol en in 1457 ijverde de anti Rolin-groep voor de installatie van een reformatie-commissie - waarvan slechts een enkel precedent in 1416 aan te stippen valt, - die voor doel had de hertogelijke ambtenaren aan een onderzoek te onderwerpen over delikate thema's zoals de herkomst van hun fortuin, en eventuele fiscale fraudes ${ }^{13}$. In het begin der vijftiende eeuw was de Bourgondische hertog tot twee maal toe gedwongen de ontvanger van Bourgondië Joceran Frepier wegens fraude uit zijn functie te ontzetten, in 1404, en in 1413 na een eerste rehabilitatie ${ }^{14}$. Jan de Bruine, een secretaris van Filips de Stoute, ac-

(New York, 1967) 66, noot 9, is het hier niet mee eens, maar ik ben geneigd althans hier de visie van Pirenne bij te treden.

10. Buntinx, De audiëntie, 98-99. Een belangrijke factor voor deze ontwikkeling is de massificatie in de ambtenarenwereld, die precies in de veertiende eeuw inzet: bv. het Parijse Parlement telt 20 raadsheren in 1314,en 62 in 1343; cf.tal van voorbeelden in: B. Guenée, L'Occident aux XlVe et XVe siècles. Les Etats (Parijs, 1971) 197.

11. W. Prevenier, 'Quelques aspects des comptes communaux en Flandre au moyen-age', in: Financiën en boekhouding, 130.

12. E. Feys-D. van de Casteele, Histoire d'Oudenbourg, II (Brugge, 1873) 406.

13. J. Bartier, 'Une crise de 1'état Bourguignon: la réformation de 1457', in: Hommage au professeurPaul Bonenfant (Brussel, 1965) 501-511.

14. A. van Nieuwenhuysen, 'La comptabilité d'un receveur de Philippe Ie Hardi', in: Ibidem, 409-419. 


\section{W. PREVENIER}

cepteerde in 1392 geschenken om de rekeningen van de burggraaf van Beveren als grafelijk ambtenaar niet te verifiëren ${ }^{15}$. Belangrijker echter lijkt me de aanwezigheid bij de vijftiende eeuwse ambtenaren van een duidelijk streven naar sociaal prestige. Uiteraard maakten de ambtenaren, vooral de hoge ambtenaren toen een snelle ontwikkeling door; zij werkten in de onmiddellijke omgeving van de hofkringen met hun typische herfsttijdelijke levensstijl, dat wonder mengsel van archaïsche elementen, hunker naar het verleden (zie bv. het najagen van een voorbij kruistochtideaal, het voortzetten van bepaalde ridderlijke militaire denkbeelden) en tevens het opengooien van vensters op de nieuwe wereld die zich aankondigt (zie bv. de idee van de moderne centrale staat, waarin de Nederlanden al dan niet los van een andere natie gezien werden). De ambtenarenstand in het algemeen is een soort tweelingbroertje van de hofkringen. Zoals Filips de Stoute en Filips de Goede hun mecenaat rijkelijk uitstrooiden over kunstenaars als Klaas Sluter, Jan van Eyck en Memling, liet kanselier Nicolas Rolin het hospitaal te Beaune rijk versieren met wandtapijten en met het unieke polyptiek 'Het Laatste Oordeel' van Rogier van der Weyden, en liet hij zich portretteren door Van der Weyden en Jan van Eyck. En ook Philips van Croy werd vereeuwigd door Rogier van der Weyden. Dat hoorde nu eenmaal bij de status van deze hoge middens ${ }^{16}$. Zoals hertog Filips de Goede er 33 maitresses op na hield, die het leven schonken aan minstens 26 hertogelijke bastaardkinderen, zo werd voor Jan van Bourgondië, zelf bastaard van Jan zonder Vrees, in Kamerijk in 1480 een overlijdensmis opgedragen door zijn 36 onwettige kinderen en kleinkinderen; een detail nog: Jan van Bourgondië was bisschop van Kamerijk geweest ${ }^{17}$. Bastaarden waren toen statussymbolen, net als de schilderijen van Van Eyck. Terwijl het voor ambtenaren en hofkringen in de vijftiende eeuw de bon ton was om de overtollige kapitalen te investeren in mecenaat van schilders en beeldhouwers, belegde men in de veertiende eeuw in beide milieus, materialistischer, deze kapitalen in grondaankoop, en ging men er in de zestiende eeuw schoolstichtingen mee financieren.

Deze osmose van ambtenaren enerzijds, hofkringen en grafelijke of hertogelijke familie anderzijds, is een klassiek merkteken voor de vijftiende eeuw, en ook hier heeft de zestiende eeuw slechts een begonnen evolutie verder gezet. Het behoorde tot de normale ambitie van de adellijke kringen der zestiende eeuw om carrière te maken, en hoge posten zoals prinvinciegouverneur na te streven. En de beste methode bleek, zoals in de vijftiende eeuw, toegang te verwerven tot de hofmilieus

15. Buntinx, De audiëntie, 142-144.

16. A. Kleinclausz, 'Les peintres des ducs de Bourgogne', Revue de l'art ancien et moderne, XX (1906) 161-176, 253-268; J. Huizinga, Herfsttij der middeleeuwen (7e dr.; Haarlem, 1950) 328-329.

17. M. Berge, 'Les bâtards de la maison de Bourgogne', L'intermédiaire des généalogistes, LX (1955) 316-408, inz. 321. 
in ruime $\operatorname{zin}^{18}$. De lijn was overigens niet circa 1400 gestart. Reeds midden veertiende eeuw zijn enkele symptomen merkbaar die in dezelfde richting gaan. Simon de Mirabello, bastaard van een Italiaanse lombaard uit Asti, vestigde zich met zijn vader ca. 1300 in de Nederlanden, huwde met Isabella van Lierde, een bastaardzuster van Lodewijk van Nevers, de Vlaamse graaf, en maakte een mooie carrière in de Vlaamse ambtenarij ${ }^{19}$. Het is het begin van een nieuwe toestand, want hij was een der weinige Italianen in de veertiende eeuw die zo hoog wist op te klimmen. Bij autochtone ambtenaren lukte dit in de veertiende eeuw wel al bij herhaling ${ }^{20}$. Laat ons zeggen dat het voorlopers waren van een situatie die in de vijftiende eeuw de normale werd.

Een afgebakende groep heeft de neiging zich tot een klasse af te sluiten. Dit is al duidelijk in de veertiende eeuw, door de vorming van typische ambtenaren-families. Wel was er een permanente mobiliteit van de ene naar de andere administratieve sector. In het Brussel der vijftiende eeuw liep de klassieke promotie van de onderbetaalde functie van rentmeester van een caritatieve instelling naar het stadssecretariaat of de functie van klerk in een rijke abdij ${ }^{21}$. In Vlaanderen klommen talrijke ambtenaren van een stedelijke functie op naar een der honorabele hertogelijke bestuursposten: Simon van Formelis steeg van stadspensionaris van Gent in 1400 op tot hertogelijk raadsheer in Brabant (1404) en tot voorzitter van de Raadkamer van Vlaanderen (1409-1440), en hij was slechts één uit een klasse van dergelijke carrière-makers, die vooral talrijk werd in de vijftiende eeuw ${ }^{22}$.

Om het geschetste rechtlijnige schema ietwat te relativeren (de realiteit is altijd complex), notere men dat precies bij het begin der Bourgondische periode, in 1384, in Vlaanderen het standencollege der Staten werd opgericht (naar Frans model) waarin de drie standen archaïsch elk in hun vakje gesitueerd werden volgens het patroon der twaalfde eeuw, precies terwijl de tendens naar doorbreking der standen zich duidelijk voltrok. De verklaring van deze anomahe kan hierin liggen dat dit Staten-college van 1384 e.v. slechts gecreëerd werd pour les besoins de la cause, en dus eerder de politieke taktiek van vorst en steden weerspiegelt, dan de sociologische verhoudingen der $\operatorname{standen}^{23}$.

18. M. Baelde, 'Edellieden en juristen in het centrale bestuur der zestiende-eeuwse Nederlanden, 1531-1578', Tijdschrift voor Geschiedenis, LXXX (1967) 40-41, situeert de start van de 'grote trek' naar de vorstelijke omgeving onder de eerste Bourgondiërs.

19. Rogghé, 'Simon de Mirabello', 5-9.

20. Buntinx, De audiëntie, 101-103.

21. E. Fobe, 'De huisarmen van de parochie St. Jakob-op-de-Koudenberg te Brussel in de XVe eeuw' (onuitgegeven proefschrift ,R.U. Gent, 1971) 21-28, geeft interessante voorbeelden van dergelijke carrières.

22. E. de Borchgrave, 'Fourmelles (Simon de)', Biographie Nationale, VII (Brussel, 1880-1883)

kol. 214-217; Rogghé, 'De Gentse klerken', 118-120.

23. W. Prevenier, De Leden en de Staten van Vlaanderen (1384-1405) (Brussel, 1961) 61-75. 


\section{W. PREVENIER}

De sociale mobiliteit der veertiende-vijftiende eeuw, in het bijzonder dan in de ambtelijke wereld, heeft een krachtige impuls ontvangen van een exogene factor, nl. het proces van technocratisering en groeiende scolarisatie. Vanuit de universiteiten van Bologna, Orléans en Parijs was een klasse van universitair geschoolde juristen gegroeid die het karakter van de ambtenarenstand circa 1300 grondig heeft veranderd ${ }^{24}$. Ik vermeld pro memorie de betekenis van de met Romeins recht doordrongen legisten van de Franse koning Filips August voor de opbloei van een nieuwe centralistische staatsconceptie in Frankrijk. Met het oog op het gestelde probleem is het nuttig even de preciese chronologische etappes na te gaan van de introductie van juristen, en dus van de technokratisering in de administratie der Nederlanden op stedelijk en landsheerhjk niveau. Door de studie van Prof. J. Gilissen weten we zeer precies dat reeds op het einde van de dertiende eeuw talrijke gespecialiseerde en juridisch (meestal universitair) geschoolde klerken en pensionarissen werden aangeworven door de Vlaamse graaf en de grote Vlaamse steden Gent, Brugge en leper. Meer bepaald kwamen in de grafelijke raad vanaf 1309 steeds juristen of legisten voor en sinds 1327 hebben de legisten de politieke besluitvorming in handen ${ }^{25}$. Sindsdien waren de kanseliers steeds legisten. De stad Gent stuurde reeds in 1295 talrijke studenten naar de Parijse Sorbonne, die later in de stad als bevoegde juristen in dienst zouden treden ${ }^{26}$. In de veertiende eeuw ontleenden de kleine steden meestal hun taalmannen tijdelijk bij de grote steden. Vanaf het einde der eeuw zien we echter ook op dat niveau de technocratie doorbreken: de kasselrijen Oudenaarde en Kortrijk bezaten eigen geschoolde klerken tenminste vanaf 1388, Nieuwpoort en Sluis vanaf 1391. Geraardsbergen vanaf 1392, Dendermonde, Kortrijk en kasselrij Veurne vanaf 1393, zelfs een stadje als St. Anna ter Muiden in 1400. Het waren niet allen universitairen, maar de doorbraak van de ambtenaar-technicus is er toch scherp in de tijd door gesitueerd en het is duidelijk dat het zuiden voorop lag op het noorden ${ }^{27}$. Dat proces van specialisatie greep

24. E. I. Strubbe, 'De receptie in de Vlaamse rechtbanken van midden $14 \mathrm{e}$ tot einde $15 \mathrm{e}$ eeuw', Tijdschrift voor Rechtsgeschiedenis, XXIX (1961) 450, meent dat de introductie van het geleerde (Romeinse) recht in de justitieraden, precies de technocratisering op het vlak der stedelijke functies (pensionarissen) geprovoceerd heeft.

25. J. Gilissen, Les légistes en Flandre aux XIIIe et XIVe siècles, Hand. Kon. Comm. v. Uitgave Oude Wetten en Verord. v. België, XV (1939) 117-231; M. Vandermaesen, 'Raadsheren en invloeden achter de grafelijke politiek in Vlaanderen in de 14e eeuw', in: Handel, v. h. XLIe Congres (Mechelen 1970) van de Fed. v. d. Kringen v. Oudh. en Gesch. v. België (1970) 215. Uitvoeriger in zijn onuitgeg. lic. verhandeling: 'Grafelijke residentie en centrale bestuursinstellingen in Vlaanderen tijdens de regering van graaf Lodewijk II van Nevers' (Gent, 1969). Ook in 1404-1405 stuurt Gent studenten naar Parijs, die later als stads-legisten fungeren (S.A. Gent, Stadsrek. 1404-1405, fo 99 $\left.\mathrm{v}^{\circ}-100 \mathrm{r}^{\circ}\right)$.

26. Rogghé, 'De Gentse klerken', 25-27.

27. Kasselrij Oudenaarde: W. Prevenier, Handelingen van de Leden en v. d. Staten van Vlaanderen (1384-1405) (Brussel, 1959) $\mathrm{n}^{\circ}$ 55, 57, 77, 90-91, 102, 106, 182; kasselrij Kortrijk: ARA, Brussel, R.(eken)k(amer), 42.890, fo $15 \mathrm{v}^{\circ}$; Nieuwpoort: ARA, RK, 36.701, f $13 \mathrm{v}^{\circ}$; Sluis: 
steeds verder om zich heen in de vijftiende eeuw: voor Gent bijvoorbeeld is bekend dat het aantal advocaten en meesters in stadsdienst in de vijftiende eeuw aanzienlijk hoger lag dan in de veertiende eeuw. Terwijl in de dertiende eeuw een ambassade gezelschap nagenoeg steeds uit edelen was samengesteld, ontbrak daarin sinds het einde van de veertiende eeuw bijna nooit een jurist. Het is een intensifiëring, maar geen wijziging van een rond 1300 ingeslagen koers. De vijftiende eeuw toont in de Nederlanden de triomftocht voor de geleerde juristen in heel het sociale leven ${ }^{28}$. Volledigheidshalve moet ik hier aan toe voegen dat reeds in de dertiende eeuw zich in de ambtelijke milieus een evolutie voltrok van het zeer traditioneel feodaal bestuursapparaat naar een fonctionarisme, waarbij de ambtenaren rationeler en beter geschoold waren ${ }^{29}$.

Een tweede sector van technocratisering is die van de financiële techniek, de kredietvorming en de boekhouding. Zoals voor de herleving van het recht, kwam ook hier de vernieuwingstendens uit Italië. In de eerste helft der veertiende eeuw doken nogal wat Italianen op in de Nederlanden, als privé financiers doch ook als ambtenaren of semi-staatsambtenaren. Een eerste golf Italiaanse financiers (lombarden) en wisselaars namen in de Nederlanden na 1300 de rol over die tot dan toe de financiers van Atrecht in de geldhandel en het kredietwezen gespeeld hadden ${ }^{30}$. Het is merkwaardig hoe spoedig velen onder hen zich, door hun technische superioriteit, wisten in te burgeren in de vorstelijke omgeving of in de steden: Jan de Mirabello uit Asti werd in 1323 rentmeester van de hertog van Brabant, Simon de Mirabello werd ontvanger van de graaf van Vlaanderen in 1329. Ottelin Machet uit Firenze was algemeen ontvanger in 1334-1335, naast tal van andere functies, zoals ook Conté Gualterotti, die tevens ontvanger van Gent was geweest ${ }^{31}$. Men mag toch redelijkerwijze aannemen dat de aanwezigheid van deze Italiaanse financiers helpt verklaren waarom de Nederlanden, speciaal Vlaanderen, op het vlak van financiële techniek en boekhouding progressiever waren dan bv. het Hanze-milieu. Weliswaar was er

Prevenier, Ibidem $\mathrm{n}^{\circ}$ 182, g; Geraardsbergen: ARA, RK, 35.231, $\mathrm{f}^{\circ} 16 \mathrm{r}^{\circ}-18 \mathrm{r}^{\circ}$; Dendermonde: ARA, RK, 37.978, f $^{\circ} 17 \mathrm{r}^{\circ}-21 \mathrm{v}^{\circ}$; Kortrijk: ARA, RK, 33.147, f $16 \mathrm{v}^{\circ}$; kass. Veurne: ARA, RK, 43.102, f" $29 \mathrm{r}^{\circ}$; St. Anna ter Muiden: ARA, RK, 36.547, f $6 \mathrm{v}^{\circ}-7 \mathrm{r}^{\circ}$.

28. Rogghé, 'De Gentse klerken', 110-111; R. C. van Caenegem, 'Boekenrecht en Gewoonterecht', in: Bijdragen en Mededelingen van het Historisch Genootschap, LXXX (1966) 26-27.

29. E. I. Strubbe, Egidius van Breedene. Grafelijk ambtenaar (Brugge, 1942) 90-95; Th. Luykx, 'Etude sur les chanceliers de Flandre pendant le règne de Jeanne de Constantinople', Revue du Nord, XXXII (1946) 256. Uiteraard kan men ook een proces van bureaucratisering vaststellen dat reeds in de veertiende eeuw afschrikwekkende vormen aannam; rond 1332-1333 zou de Franse kanselarij reeds ca. 35.000 documenten afleveren per jaar, zie: R. H. Bautier, Recherches sur la chancellerie royale au temps de Philippe VI (Parijs, 1966) 179-180.

30. G. Bigwood, Le régime juridique et économique du commerce de l'argent dans la Belgique du moyen-âge, I (Brussel, 1921) 175-179 (financiers v. Atrecht), 179-255 (Italianen); C. Tihon, 'Aperçus sur 1'établissement des Lombards dans les Pays-Bas aux XIIIe et XI Ve siècles', Revue Belge de Philologie et d'Histoire, XXXIX (1961) 334-364.

31. Rogghé, 'Italianen te Gent', e.a. artikels (cf. noot 4). 


\section{W. PREVENIER}

steeds een achterstand tegenover Italië. Nadat in 1340 te Genua de dubbele boekhouding in gebruik was gekomen, gingen in de jaren 1366-1370 de Brugse geldwisselaars Colard van Marke en Willem Ruweel nog steeds door met enkel boekhouden, maar overigens gelijken de Brugse grootboeken zeer nauwkeurig op die der Genuese bankiers. Dit bewijst dat men in de lage landen inderdaad waarde hechtte aan het verfijnen van de bestuurstechniek ${ }^{32}$.

In een recente studie over het kantoor der Hanzeaten te Brugge in de vijftiende eeuw, poneerde de auteur, Dr. Leloux, dat de juridische technocratisering van het Hanze-secretariaat wel eens het antwoord zou kunnen zijn op de technocratisering van het Bourgondisch staatsapparaat ${ }^{33}$. Ik meen dat deze stelling niet alleen juist maar zelfs voor uitbreiding vatbaar is. Op soortgelijke wijze leidde bijvoorbeeld de creatie van het moderne financiële apparaat en kontrolelichaam der Rekenkamer van Rijsel in 1386 er toe dat het primitieve karakter der Vlaamse stadsrekeningen zich stilaan ontwikkelde tot een gedegen en ordelijk boekhoudingssysteem; de kontrolesessies van de hertogelijke commissarissen maakten dit nodig ${ }^{34}$.

De zestiende eeuw geeft eigenlijk geen structureel verschillend beeld te zien. De eis naar specialisatie op de twee genoemde terreinen ging onverminderd door. De Geheime Raad bevatte uitsluitend juridisch gevormde raadsheren, en was een mooi voorbeeld van efficiënte technocratie; in de Raad van Financiën zaten naast financiële experts weliswaar ook hoog-adellijke politici, maar het streven om meer technici te benoemen werd steeds duidelijker. Vanaf 1535 deed ook in de Raad van State een niet onaanzienlijk aantal rechtsgeleerden zijn intrede en zij vormden in de volgende decenniën een groep die numeriek vrijwel gelijk was aan die der edellieden. In de jaren zeventig der zestiende eeuw was het aantal juristen en technici in de in 1531 opgerichte Collaterale Raden reeds aanzienlijk groter dan in het begin en dit was ten koste van de edellieden gegaan ${ }^{35}$. Zoals in de vorige eeuwen bleef de hoge adel aanwezig. Er kan enkel sprake zijn van een schaalvergroting. De bureaucratisering en het steeds complexer worden der samenleving dwong de overheid steeds meer technici te benoemen in de overheidssector.

Deze technocratisering der late Middeleeuwen wijzigde de verhouding van de vorst tot zijn ambtenarenapparaat totaal. Dit proces liep in de tijd volkomen parallel met

32. O. ten Have, 'De geschiedenis van het boekhouden', in: Maandblad voor bedrijfsadministratie en organisatie, LXXV (1971) 63 en 131; R. de Roover, 'Le livre de comptes de Guillaume Ruyelle, changeur à Bruges (1369)', Hand. Genootschap Soc. Emulation te Brugge, LXXVII (1934) 67.

33. H. Leloux, 'Zur Sprache in der ausgehenden Korrespondenz des Hansischen Kaufmanns zu Brügge' (onuitgegeven doet., Gent, 1971) I, 10.

34. M. Bruchet, Répertoire numérique. Archives dép. du Nord. Série B, 1 (Rijsel, 1921) i-xix; Prevenier, 'Quelques aspects', 122-123; aanbevelingen van de vorstelijke commissarissen voor een betere boekhouding in de steden: Ibidem, 127.

35. Baelde, 'Edellieden en juristen', 43-51. 
het voorgaande. Terwijl in de twaalfde tot dertiende eeuw de ambtenaar nog behoorde tot het type van de 'grand commis', vol eerbied voor de feodale en sociale hiërarchie, in absolute onderdanigheid en trouw (zie maar hoe Giselbert van Bergen in 1191, toevallig in Italië het nieuws vernemend van de dood van Filips van de Elzas in het H. Land, spoorslags naar zijn Henegouwse grafelijke heer ijlt om hem de kans te geven vlugger in Vlaanderen in te grijpen dan de Franse koning) ${ }^{36}$, verdween in de eerste helft der veertiende eeuw deze situatie geheel. De ambtenaar ging zich kritisch opstellen tegenover de vorst, en wanneer de omstandigheden hem dit toelieten begon hij ook de politieke besluitvorming op een bepaald niveau naar zich toe trekken. Ik schrijf deze evolutie toe aan de intellectualisering van de ambtenaar, die een technische en geestelijke superioriteit verwierf tegenover een vorst die in de traditie bleef steken. In de Nederlanden vind ik duidelijke symptomen van deze gewijzigde situatie vanaf het begin der veertiende eeuw; bv. in maart 1332 wanneer de kanselier Willem van Auxonne, en de financiële ambtenaren Vanne Guy en meester Pieter van Dowaai, aan de niet zeer krachtdadige graaf van Vlaanderen, Lodewijk van Nevers een staat van de grafelijke financiën voorleggen, die er door de grafelijke spilzucht alles behalve rooskleurig uit ziet; ze voegen er heel kordaat aan toe dat ze dadelijk ontslag zullen nemen, indien de graaf zijn levenswijze niet verandert $^{37}$. In 1335 weigeren dezelfde kanselieren de grafelijke ontvanger Nikolaas Guidouche een toelage uit de schatkist voor grafelijke deelname aan een toernooi $^{38}$.

Deze evolutie leidde echter nog tot belangrijker konsekwenties. Indien de vorst een niet zeer sterke persoonlijkheid is, zoals Lodewijk van Nevers, nemen de topambtenaren gretig de functie der politieke besluitvorming in handen. De kans daartoe werd geboden door de vele afwezigheden van de graaf uit het graafschap; de plaatsvervangende 'ruwaards' lieten de effectieve leiding over aan de raadsheren, waarin vertegenwoordigers van de steden het hoge woord voerden, doch waarin vooral kanselier Willem van Auxonne de sterke man werd. Het ging zo ver dat het bestuursapparaat geheel lam lag, niet wanneer de graaf, doch wanneer de kanselier uit het land was. De machtspositie van de kanselier werd als het ware geconcretiseerd in het feit dat hij het grafelijk zegel in bezit heeft ${ }^{39}$ Zelfs de ruwaard, officiële plaatsvervanger van de graaf tijdens diens buitenlandse reizen, kon geen beslissingen treffen in verband met het grafelijke domein of de financiën zonder het advies van de kanselier ${ }^{40}$. Het doet zowat denken aan de 'leerling-tovenaar'; de vorst

36. L. Vanderkindere, Le chronique de Gislebert de Mons (Brussel, 1904) 258-259; L. König, 'Die Politik des Grafen Balduin V von Hennegau', Bulletin de la Commission Royale d'Histoire, LXXIV (1905) 347-348.

37. F. Blockmans, 'Le contrôle par le prince des comptes urbains en Flandre et en Brabant au moyen-âge', in: Financiën en boekhouding, 336.

38. Vandermaesen, 'Raadsheren en invloeden', 218.

39. Ibidem, 216-218; passim in zijn onuitgegeven proefschrift.

40. Vandermaesen, 'Grafelijke residentie', 74-76. 


\section{W. PREVENIER}

is voor zijn dagelijkse kleine en grote uitgaven afhankelijk van degenen aan wie hij de bevoegdheden zelf afgestaan heeft. Het 'apparaat' gaat los en zelfstandig werken. Een vorst als Lodewijk van Male had evenwel veel beter zijn ambtenarenapparaat in handen ${ }^{41}$.

Deze machtspositie der ambtenaren is ook in de Bourgondische periode een constante. Wanneer in 1399 dienaren van de Franse koning hertog Filips de Stoute komen dagvaarden over een geschilpunt met de leperlingen, verklaart hij dat hij geen beslissingen kan treffen, wanneer zijn kanselier niet aanwezig is ${ }^{42}$, en ook de Vlaamse Leden worden vaak voor belangrijke beslissingen door de hertog naar de kanselier verwezen, en dat niet alleen uit taktische overwegingen ${ }^{43}$.

De ingewikkelde structuur van de Bourgondische staat, met gewesten in het noorden en het zuiden, geografisch gescheiden, maar ook totaal verschillend van tradities en mentaliteit, heeft het overlaten van het beleid, en dus de machtspositie der ambtenaren in de hand gewerkt. De vorsten konden niet overal tegelijk aanwezig zijn.

In de zestiende eeuw duurde deze toestand voort, met dien verstande dat vorsten als Karel V en Filips II over een groot rijk gingen regeren wat een zeer groot en liefst onderdanig korps noodzakelijk maakte, en dat de positie tegenover de vorst stilaan een ideologische ondergrond ging krijgen, nl. pro of contra centralisme, en pro centralisme in het kader van een groot-Habsburgs rijk of centralisme in het kader van de Nederlanden. Er waren de ambtenaren die het centralisme in Spaanse zin voorstonden, zoals een Granvelle. Het ziet er wel naar uit dat homines novi zoals Viglius en Lodewijk van Schore, die voorbeelden zijn van carrière-juristen, door de vorst aangetrokken werden om tegengewicht te vormen tegen de carrière-adel, en dus als pijlers van het groeiend vorstelijk centralisme. Er zou moeten onderzocht worden of dergelijke mensen wel beantwoord hebben aan de vorstelijke verwachtingen, en of zij, met veel voorzichtigheid, zich niet kritisch zijn gaan opstellen tegenover het vorstelijk centralisme, dat ze weliswaar wilden bevorderen, doch dan vanuit de optiek en in het belang van de Nederlanden gezien als een eigen politieke entiteit, los van Spanje. Welke en hoeveel raadsheren deze respectieve visies aanhingen, werd nog niet onderzocht, en het zal wel zo zijn dat bepaalde figuren, zoals Viglius, allerlei tussenposities hebben ingenomen ${ }^{44}$.

41. Buntinx, De audiëntie, 96-103.

42. Prevenier, De Leden en de Staten, 282-283, 341-342; E. Lameere, Le grand conseil des ducs de Bourgogne (Brussel, 1900) 11-13.

43: Arch. Dép. du Nord, Rijsel, B 18.822 f 268 ; ARA, Brussel, RK, no. 42.527, P 42 v-43 r ${ }^{\circ}$ $\left(a^{\circ} 1403\right)$.

44. Baelde, 'Edellieden en juristen', 43; de hier geformuleerde these is een allusie op een studie die mijn collega Baelde in de toekomst hoopt uit te werken; ik dank hem zeer voor de suggesties. M. Baelde wees in: 'De betekenis van de centrale instellingen in de zestiende-eeuwse Nederlanden' Handelingen v. h. XXVIIe Vlaams Filologencongres (Brussel, 1969) 186 er op dat de Geheime Raad in de zestiende eeuw het bestuursorgaan was dat op allerlei vlakken de centralisatie in de hand 
Aan de hand van deze laatste voorbeelden is duidelijk dat het proces van aliënatie tussen vorst en ambtenaren of vorst en onderdanen een nationaal trekje kon krijgen. Dit is ongetwijfeld zo in de zestiende eeuw. Bij het begin van de Opstand, en onder Alva, is er reeds een duidelijker scheidingslijn tussen Spaans- en koningsgezinde raadsheren enerzijds en meer nationaal-Nederlands-denkende raadsheren anderzijds. De aan de koning 'getrouwe' raadsheren zijn in de eerste plaats vreemdelingen - Spanjaarden - maar ook inheemsen, meer bepaald een aantal juristen ${ }^{45}$. De 'nationaal' geöriënteerden waren essentieel inheemsen, in het begin der zestiende eeuw vooral edelen, in het midden der eeuw ook juristen ${ }^{46}$. Ook hier zijn de etappes van het proces, dat in de zeventiende en achttiende eeuw zonder hiaat doorloopt, nog niet bestudeerd, doch ik vermoed dat deze tegenstellingen in elk geval rechtstreeks aansluiten met de factievorming die ook al op het einde der vijftiende eeuw aanwezig was onder hertog Filips de Schone. Diens vader en voorganger Maximiliaan was in de Nederlanden steeds een 'vreemdeling'geweest. Filips de Schone wist zijn populariteit aanzienlijk te verhogen door zich te omringen met talrijke autochtone raadsheren uit de inheemse adel. Filips de Schone voerde ook een politiek die meer op de Nederlanden dan op Habsburg gericht was. Dit alles belette niet dat hij een centralistische politiek voerde ${ }^{47}$.

En zo kunnen we de lijn terugvoeren doorheen de gehele Bourgondische periode, want het introduceren van vreemdelingen uit het moederland of uit een ander territoriaal bezit van de vorst was een tendens die ook al onder de eerste Bourgondiër Filips de Stoute bleek, toen hij in 1386 een aantal Fransen (Bourgondiërs nl.) in de Vlaamse instellingen binnenbracht ${ }^{48}$.

En zelfs in het begin der veertiende eeuw was dat al het geval, toen de in Frankrijk gevangen Lodewijk van Nevers in 1323 onder zware druk van de Franse koning een aantal Fransen als raadsheren opgedrongen kreeg, nl. de bisschop van Atrecht en Willem Flotte, later in 1323-24 Artaud Flotte, als voogd van de graaf, en in 1325 Willem van Auxonne als kanselier; vermits gelijktijdig Vlaamse legisten uit de Raad verdwijnen, kunnen we dit alles als een bewuste Franse politiek zien ${ }^{49}$.

In deze gevallen gaat het niet steeds over een aliënatie tussen vorst en ambtenaren,

heeft gewerkt, doch dat een centralisatiepolitiek zoals de homologatie van de costuimen eigenlijk sterk herinnert aan de bewerking der Vlaamse keuren door de Vlaamse raadsheren-juristen van de graaf in de veertiende eeuw; ook hier is dus de tendens niet na 1500, doch reeds na 1300 gestart. 45. Over de introductie der Spanjaarden onder Alva vanaf 1567: M. Baelde, De Collaterale Raden onder Karel V en Filips II \{1531-1578) (Brussel, 1965) 79-81.

46. E. I. Strubbe, 'Staatsinrichting en krijgswezen', in: Alg. Gesch. Ned., IV, 138-139: de nationale edelen voelden zich in het begin der zestiende eeuw verdrongen door de vreemde edelen in de vorstelijke omgeving, en traden op als spreekbuis van de nationaal-gestemde openbare mening in de Nederlanden.

47. Hugenholtz, 'Crisis en herstel van het Bourgondisch gezag', 27-38.

48. Buntinx, De audiëntie, 53; over het verzet der Vlaamse leden tegen deze politiek vanuit een nationaal en Nederlands taaistandpunt, zie: Prevenier, De Leden en de Staten, 210-215, 219-221.

49. Vandermaesen, 'Raadsheren en invloeden', 216-217. 
maar wel steeds tussen overheid en onderdanen, want de Vlaamse steden hebben zich tegen het opdringen van vreemde ambtenaren met kracht verzet; met name in hun grievenkohier aan Jan zonder Vrees uit 1405, waarin ze protesteren tegen het optreden van de Raadkamer van Rijsel en eisen dat deze naar Vlaanderen zou verhuizen, en de processen in het Nederlands zouden gevoerd worden. Niet enkel de taal werd hier geviseerd, maar ook de aanwezigheid van vele Bourgondiërs en Fransen in die Raad. Deze houding is ook in de Gentse opstand van 1453 aanwezig $^{50}$.

Een zoveelste variant op het eeuwige thema van de xenophobie? Men moet nochtans voorzichtig zijn bij het hanteren van actuele noties, en bijvoorbeeld niet dadelijk xenophobie in vaste correlatie zien met nationalisme. De term l'esprit national' om de hierboven geschetste mentaliteit in ambtelijke kringen aan te duiden komt pas in de achttiende eeuw op, doch de inhoud ervan is natuurlijk voordien aanwezig $^{51}$. Er ligt nog een onderzoekterrein braak om na te gaan of bij de vijftiendezestiende eeuwse ambtenaren, en sinds wanneer precies, de politieke idee aanwezig is van een Bourgondisch nationale solidariteit, een solidariteit der Nederlanden (versus Frankrijk-Bourgondië, Habsburg of Spanje), ofwel of het hier slechts ging om de eenvoudige psychologische aversie tegen vreemdelingen die de plaatsjes van autochtonen kwamen afschuimen. Het argument was veelal dat de vreemdelingen niet vertrouwd waren met de taal en de mentaliteit van het land ${ }^{52}$. Is niet door diezelfde achtergrond te verklaren dat het eveneens uit Italië in de Nederlanden geimporteerde notariaat - de eerste notaris, een Italiaan dook op in Yvoix, Luxemburg, in 1269 - hier weinig weerklank vond in de late Middeleeuwen, en het niet heeft kunnen opnemen tegen autochtone producenten van oorkonden van vrijwillige rechtspraak zoals de stadsschepenen en de officialen ${ }^{53}$ ?

De handige vreemdelingen hebben steeds zich, bv. via huwelijken, in de leefwereld der lage landen trachten te integreren: Simon de Mirabello huwde met een bastaard-

50. Buntinx, De audiëntie, 50-53. Over het protest der Vlaamse Leden bij de Blijde Intrede van Jan zonder Vrees in 1405:Verzameling van XXIV origineele charters, etc. (Gent, [1787-1788]) 2-6 van tekst 7 (doorlopend 36-40). Ook in Brabant werden in de periode 1404-1406 bij het gouverneurschap van de Bourgondiër Antoon heel wat Vlaams-Bourgondische ambtenaren in het Brabants apparaat binnengebracht, zie: A. Uyttebrouck, 'Le gouvernement du duché de Brabant au moyen-âge (1355-1430)' (onuitg. doct., U.L.B, (ter perse); Brussel, 1971) I, i, 260-261.

51. In de kroniek Die Wonderlijcke Oorloghen van keyser Maximiliaen, uitgegeven door W. Jappe Alberts (Groningen, 1957) over de gebeurtenissen van 1477-1482, doch opgesteld vm. begin zestiende eeuw, klinkt duidelijk een Bourgondisch-nationaal, anti-Frans sentiment op (zie o.m. 21 en 46).

52. Prevenier, De Leden en de Staten, 281-282: dit argument wordt althans gehanteerd door de hertogin zelf in 1394 (AD Nord, Rijsel, B 18822, $\mathrm{f}^{\circ}$ 268) en door de hertog in 1405: Verzameling van XXIV origineele charters, 2, van tekst 7, doorlopend 36.

53. H. Nélis, 'Les origines du notariat public en Belgique (1269-1320)', Revue Beige de Philologie et d'Histoire, II (1923) 271; J. Yernaux, 'Les notaires publics du 13e au 16e s., spécialement au Franc de Bruges', Bulletin de la Commission Royale d'Histoire, LXXXII (1913) 111-182. 
zuster van Lodewijk van Nevers, en werd dan Simon van Halen, bijna een autochtoon $^{54}$. Een ander merkwaardig aanpassingsfenomeen heb ik kunnen vaststellen bij de meestal uit Westfalen herkomstige secretarissen van het Hanzekantoor te Brugge. Deze mensen hanteren van huize uit Nederduits, doch pasten dit in belangrijke mate aan aan het Westvlaamse Nederlands van de Bruggelingen om zich in hun handelsrelaties meer verstaanbaar te maken. Hun basis-Nederduits wordt dus grillig doorspekt met Vlaams, maar ook met opvallend veel aan het Frans ontleend woordgebruik ${ }^{55}$. Een van deze Duitse secretarissen wist in 1393 de dochter van een rijke Brugse koopman Christiaan de Coekelare te huwen. Dat was er kennelijk een die zich op stuk van mentaliteit en taal zo zeer had geassimileerd met de Vlaamse omgeving, dat er ook op het meer sentimentele vlak voor hem geen taaigeheimen meer waren ${ }^{56}$.

Ik heb er reeds op gewezen hoe de bundeling van vertrouwensposten, machtspositie en financiële verantwoordelijkheden, de ambtenaren permanent in verleiding bracht tot fraude en corruptie, in elk geval tot het najagen van illegale materiële voordelen. Ik wil nog even wijzen op een tendens die ik eveneens vooral in de veertiende eeuw zie opduiken, de tendens die we litterair kunnen omschrijven door te verwijzen naar Carlo Goldoni's 'Knecht van twee meesters', doch dan schrijven we al 1745. De dubbelhartige moraal, of is het gewoon maar jacht op materieel voordeel, van tegelijk in dienst te kunnen staan van twee tegenstrijdige instanties of belangengroepen, is duidelijk aanwezig op het einde der veertiende eeuw. Niclais Scoorkinne, pensionaris, dit is juridisch geschoold ambtenaar, in dienst van de stad Brugge van 1379 tot 1414, en door die stad belast met hoogst vertrouwelijke diplomatieke opdrachten, zoals de handelsconferenties tussen Vlaanderen en Engeland circa 1400, waarin de belangen van de Bourgondische hertog en de Vlaamse stedelijke milieus niet geheel parallel liepen, heeft in diezelfde jaren allerlei diensten bewezen aan de Bourgondische hertog, waarvoor hij in 1387 beloond werd met het vruchtgebruik van een residentie bij Brugge 'pour considération des bons services qu'il nous (= de hertog) a fais en temps passé ... et fait de jour en jour'. De hertog noemt hem zelfs zijn 'amé et féal conseiller ${ }^{57}$. Een merkwaardig voorbeeld levert de bekende Henegouwse adellijke familie der Croys, die in de machtstrijd om de voorrang aan het Bourgondische hof met de groep van kanselier Rolin, in 1457 de bovenhand wist te krijgen, en de ongenade van Rolin wist te bewerkstelligen. Terwijl de Croys hun functies aan het Bourgondische hof verder bleven uitoefenen, ontvingen ze

54. Bigwood, Le régime juridique, 305-312.

55. Leloux, 'Zur Sprache in der ausgehenden Korrespondenz', I, 221-310.

56. L. Gilliodts-van Severen, Inventaire des archives de la ville de Bruges, le serie, II (Brugge, 1873)262.

57. W. Prevenier, 'Scoorkinne (Niclais)', in: Biographie Nationale, XXX (Brussel, 1959) kol. 761-763; Rogghé, 'De Gentse klerken', 103-104. 


\section{W. PREVENIER}

tegelijk vanwege de Franse koning Lodewijk XI, de politieke tegenspeler van hun hertog, belangrijke en flink betaalde ambten in Frankrijk. De Croys hadden Lodewijk XI leren kennen als dauphin tijdens diens vrijwillige ballingschap in de Nederlanden, en Chastellain beschrijft de broers Croy en de dauphin 'comme trois testes en un sac toujours ensemble'. Men mag aan de invloed van de Croys toeschrijven dat Filips de Goede inging op het voorstel van de Franse koning om de Sommesteden te verkopen in $1463^{58}$. Moeten we deze dubbele functie en rol als 'verraad' beschouwen, op grond van aktuele morele beschouwingen? Prof. J. Bartier en P. Bonenfant zijn geneigd begrijpend te staan tegenover de 'dubbele trouw' der Croys, en zien het als een psychische behoefte, in overeenstemming met de gewoonten en tradities van de tijd ${ }^{59}$. Ik meen echter dat de tijdgenoot deze toestand wel degelijk als laakbare dubbelhartigheid ervoer; een kroniekschrijver legt althans hertog Filips, wanneer hij de alliantie Franse koning-Croys door heeft, de volgende zin in de mond: 'Croy, on peut mal servir deux maistres à gré' En wanneer hertogszoon Karel de Croys op zijn zijde poogt te krijgen, repliceren ze: 'Je ne veux pas cesser le service d'un roi de France pour un comte de Charolais ${ }^{60}$. Dubbele trouw zo lang het kan, enkele trouw als het moet?

Tegen deze gang van zaken hebben ook de steden der Nederlanden zich uiteraard pogen te verzetten. Wanneer in het begin der vijftiende eeuw Etienne van Nederalphen wisselaar wordt van de stad Brussel nadat hij tot dan toe ambtenaar was van de Brabantse hertogelijke administratie, wordt hem gevraagd te beloven dat hij voortaan geen enkele relatie met de hertog meer zal onderhouden.

Samenvattend geloof ik dat een aantal evoluties in aard, samenstelling en mentaliteit van de ambtenarenstand zich aftekenen vanaf het begin of de loop der veertiende eeuw: doorbreking der standsmuren, technocratisering, kritische houding tegenover de opdrachtgever, introductie van vreemdelingen en negatieve reactie hiertegen vanwege de autochtonen, ontstaan van een dubbele moraal op het terrein van de trouw aan de opdrachtgever. Andere symptomen daarentegen, zoals de groei van een sociologische ambtenaren-entiteit met een eigen gelaat, en bepaalde vormen van specialisatie en perfectioneren zoals het inrichten van vaste diplomatieke diensten ${ }^{61}$, horen eerder in de vijftiende eeuw thuis terwijl de ontwikkeling van een

58. P. Colin, Les ducs de Bourgogne (Brussel, 1941) 233.

59. J. Bartier, 'Filips de Goede', in: Alg. Gesch. Ned., III (Utrecht, 1951) 259, neemt hier de stelling over van P. Bonenfant. Buntinx, De audiëntie, 96-103, stelt bij zijn grafelijke ambtenaren der veertiende eeuw vooral blijken van trouw vast, doch schrijft die toch essentieel toe aan het utilitaristisch najagen van voordelen verbonden aan de ambten.

60. P. Bonenfant, Philippe le Bon (Brussel, 1944) 109, 111.

61. Weliswaar werden reeds op het einde der dertiende eeuw min of meer vaste procuratores aan de voornaamste gerechtshoven gehecht, doch permanente en wederkerige diplomatieke relaties komen pas voor sinds het midden der vijftiende eeuw, het eerst in Italië: Guenée, UOccident, 214217; in de Bourgondische staat werden de Italiaanse technieken terzake pas overgenomen in 
eigen politieke visie op de staatsproblemen, op thema's zoals centralisatie of zoals de verdediging van de nationale eigenheid van de staat en van de instellingen, eigenlijk pas op het einde der vijftiende (onder Filips de Schone) en in de zestiende eeuw opduiken. Algemeen menselijke thema's zoals machtsstreven en materieel voordeelzijn natuurlijk niet tijdgebonden. Een aantal structurele wijzigingen zullen zich pas op het einde der zestiende eeuw of later voltrekken; de financieringstechniek der oorlogen verschilt niet essentieel in de vijftiende en in de zestiende eeuw, het dooreenhaspelen van staats- en privé-financiën is in beide periodes aanwezig. De verandering bestaat essentieel in schaalvergroting ${ }^{62}$.

Mijn bedoeling was slechts enkele belangrijke elementen van het probleem in het licht te stellen. Dat het breukvlak tussen oud en nieuw steeds rond 1500 zou liggen, lijkt me, althans op dit terrein, een onhoudbare stelling ${ }^{63}$.

1492 met de eerste vaste residerende ambassadeur van de Nederlanden in Engeland: A. M. Fobe, 'De Spaanse nalatenschap: een onderzoek naar de ontstaansredenen van de vroegste residerende gezantschappen vanuit de Nederlanden (1492-1506)', in: Tijdschrift voor Geschiedenis, LXXXV (1972) (ter perse).

62. J. Bouvier-H. Germain-Martin, Finances et financiers de l'ancien régime (Parijs, 1964) 50-55. 63. Ik stel er prijs op mijn collega Prof. Dr. M. Baelde en mijn assistent Drs. M. Vandermaesen van harte te danken voor hun adviezen evenals de vele deelnemers aan het congres van het Nederlands Historisch Genootschap te Driebergen (op 23 oktober 1971), die met hun bedenkingen mijn lezing hebben willen verbeteren en nuanceren. 


\title{
Sociaal-economische evoluties in de Nederlanden vóór de Revoluties (veertiende - zestiende eeuw)*
}

\author{
R. VAN UYTVEN
}

Het is een gemeenplaats geworden deLate Middeleeuwen en de zestiende eeuw tegenover mekaar te plaatsen als een age of contraction, die naar gelang de auteurs ergens vóór of na 1300 aanvangt en doorloopt tot 1450,1475 of 1500, en de daaraanvolgende age of expansion ${ }^{l}$. Deze tegenstelling wordt bovendien doorgaans verder uitgewerkt aan de hand van een gan se reeks kenmerken, die men als nieuw en typisch voor de zestiende eeuw aanhaalt, waarbij uitdrukkelijk of stilzwijgend wordt gesteld dat de Late Middeleeuwen deze niet te zien gaven of er net het tegendeel van vertoonden. Aan de hand van de literatuur is het eenvoudig een dergelijke lijst van karakteristieken aan te leggen:

xive-xve EEUWEN

honger naar edel metaal

dalende bevolking

stabiele of dalende prijzen

stijgende of hoge reële lonen

stedelijk protectionisme

corporatisme

handwerk
Xvie EEUW

toevloed van zilver

bevolkingsexplosie

'prijsrevolutie'

dalende of lage reële lonen

economisch liberalisme

bedrijfsconcentratie

'technische revolutie'

* Als voordracht gehouden op het congres van het NHG te Driebergen, 23 oktober 1971.

Zie voor de grafieken de gedrukte versie van de BMGN.

1. Voorbehoud wordt gemaakt door onder meer E. A. Kosminsky, 'Peut-on considérer le XIVe et le XVe siècle comme 1'époque de la décadence de 1'économie européenne?' in :Studi in onore di A. Sapori (Milaan, 1957) I, 551-569, en G. Fourquin, Histoire économique de l'Occident médiéval. Collection U. Histoire médiévale (Parijs, 1969) hoofdst. xiii-xvi. 